\title{
RESEARCH ARTICLE \\ Old diseases \& contemporary crisis. Inherited blood disorders in the Sultanate of Oman
}

\author{
Claire Beaudevin ${ }^{*}$ \\ IFRIS/Cermes3, Research Centre on Medicine, Sciences, Health, Mental Health and Society \\ (CNRS/Inserm/EHESS/University Paris Descartes), Paris/Villejuif, France
}

This contribution draws on ethnographic research conducted in Oman on inherited blood disorders (IBD). Interpreting results from population genomics studies that trace mutation processes over centuries of human activities, lay-representations of IBD often consider them historical evidences. The perceived spread of IBD in Oman may thus provide unusual historical depth in a country where past conflicts have been erased from historiography and representations of time are politically prescribed. Through the notions of crisis and diversification, this contribution shows how IBD's chronicity challenges the healthcare system and became a national issue, politically labelled as urgent. The paper casts light on several aspects of contemporary Omani society: it first addresses the dynamics of disease taxonomies - though biomedically described in the early 20th century, IBD were not individualized within local nosologies until the 1970s. Secondly, it shows how biomedical knowledge about IBD led to diversification within the healthcare system, through the introduction of clinical genetics, genomics, and community genetics. Thirdly, it attempts to broach modalities of the biopower exerted by the Omani regime over its citizens: IBD are targeted by various public health measures that jeopardize patients' autonomy by aiming to control their bodies through their matrimonial behaviour. In addition, two aspects of the intersections between Omani social hierarchy and IBD are noteworthy: the creation of a patients' association that constitutes a potential disturbance of the social order; and the way IBD mutations traced by genomics are considered direct historical documents that challenge representations of the recently crafted "Omanity" in a context of regional concern regarding national identities' durability.

Keywords: genetics; Middle-East; biopolitics; biosociality; inherited blood disorders

\footnotetext{
* Cermes3, Campus CNRS, 7 rue Guy Môquet, 94801 Villejuif Cedex, France - Email: claire@beaudevin.net
} 


\section{Beaudevin}

\section{Old diseases \& contemporary crisis. Inherited blood disorders in the Sultanate of Oman}

\section{Introduction}

One can avoid a crisis or experience it, fear its onset, manage its course, or sometimes solve it. But one can also wonder how a crisis is identified and defined, especially in the field of (public) health. How (and for whom) can long-known, chronic, genetic, hereditary disorders constitute a 'crisis'? What kinds of new social arrangements can these very disorders produce through their social and political impact?

Within this special issue's framework, this contribution conceives the term 'crisis' as bi-dimensional: both as a representation and an analytical tool allowing the description of deep social transformations. Drawing on the particular case of inherited blood disorders (IBD) in a Gulf country, the Sultanate of Oman ${ }^{1}$, this paper will thus deal first with the way IBD are tackled by the Omani government through the "rhetoric of crises in public health" (Parkin et $a l$. , this issue). It will then broach the healthcare pattern's crisis that one can anthropologically pinpoint in Oman and that echoes the weakening of the government's political legitimacy. In this second dimension, the crisis is considered a context of production, encompassing dimensions of uncertainty and emergency; among others, its outcomes can be diversification processes, resulting in novel social arrangements and practices. This contribution will also address several results of the diversifications - nosological, therapeutic, social and political — that occurred in the wake of public health management of IBD.

\section{Background}

An authoritarian monarchy of the Arabian Peninsula, the Sultanate of Oman has been ruled since 1970 by Sultan Qaboos bin Sa'id, who overthrew his father. At that time, the country was very poor, isolated and deprived of almost any sort of infrastructure. The American missionary hospital was the only health facility. The new sultan launched a vast modernization plan, including administration, industries, health, and education. Nowadays, Oman is a relatively wealthy 2,8 M-inhabitant country, enjoying a somewhat surprising stability given its geographical location in a frequently troubled region and the extensive economical and social changes it underwent over the course of the last four decades ${ }^{2}$.

The diseases studied in this contribution are sickle-cell anaemia and beta-thalassaemia, serious genetic chronic conditions which affect red blood cells. Among their most common symptoms are bone malformations, infections and intense pain crises. IBD are generally diagnosed in very young children after the outbreak of the first clinical symptoms. Without early therapeutic measures, they are often lethal during childhood ${ }^{3}$. Their inheritance pattern is recessive: an affected individual systematically owns two copies of the mutated genes causing the disease ${ }^{4}$. If only one mutated copy is transmitted by the parents, the child will

\footnotetext{
${ }^{1}$ Beaudevin 2010.

${ }^{2}$ For more details about history and politics of the Sultanate, see for instance Valeri 2009.

${ }^{3}$ Death of young affected people most of the time originates in a late (or absence of) diagnosis. This can take place in countries where newborn screening is not implemented and, for sickle-cell anaemia specifically, if the first pain crises are not diagnosed as sickle-cell related. Sickle-cell anaemia and thalassaemia are different diseases that produce different life experiences; however, the choice of considering them as a whole is grounded in what they share in Oman, namely some of their symptoms, part of their biomedical management and most of their related social issues.

${ }^{4}$ For more details regarding the physiopathology of sickle-cell anaemia and thalassaemia, see for instance Anionwu and Atkin 2001.
} 
only be a carrier of the disease and not suffer from any symptoms. S/he will still be able to transmit these mutated genes to his/her own offspring, however. In the case of potential parents who are carriers, the risk of giving birth to an affected child is $25 \%$, for every pregnancy. There are at least 8000 individuals affected by IBD in $\mathrm{Oman}^{5}$, i.e., about $0,3 \%$ of the population - which could appear trivial but would represent 1 million patients in the United States or 180000 in the United Kingdom given their contemporary populations. Between 3,8 \% (Centre for Arab Genomic Studies 2008) and 6 \% (Al-Riyami et al. 2001) of Omanis carry a mutation that leads to sickle-cell anaemia, and 2,5\% are carriers of a betathalassaemia mutation (Al-Riyami et al. 2001).

First within erroneous medical discourse and then in lay representations, IBD have long been described as group-specific diseases: sickle-cell anaemia has been considered confined to Black populations, thalassaemia to Mediterranean and Indian groups. Combined with misinterpretations of population genomics research (which studies distribution and migrations of human genes since prehistoric times), this has led to a global lay representation of IBD as "diseases of the origins" (Bonnet 2009). This connection between genotype, territory and ancestry remains in popular discourses, even though genomics has proved it to be not systematic ${ }^{6}$. In the United States for instance, sickle-cell anaemia has long been considered a marker of African ancestry, partly because of its discovery in a Black-American patient and its place as an important cause within the struggle for civil rights (for more details about sickle-cell anaemia's politics in the United-States, see for instance Tapper 1999; Wailoo 2001; Wailoo and Pemberton 2006). As a former colonizing nation, Oman has close historical ties with Asia (Baluchistan) and East-Africa (Swahili coast, Zanzibar), where trading posts had been implanted. Part of its population originates in these former colonies, but these various origins are mostly passed over in silence by the regime. In the Sultanate as in many other countries, lay aetiological models sometimes relate IBD to one's presumed place of origin. But this does not address a notable discrepancy between Oman and the United Kingdom or the United States: the disease is spread among most of the groups in Omani society and all over the Sultanate's territory. More broadly, these discourses and representations melting genetics with ancestry, kinship and territories fall within the realm of the current form of "politics of provenance" (Carter 2009), described by Carter and Dyson (2011, 966) as "[reinterpreting] traditional questions about social identity, personal destiny and purposefulness, political allegiances and affiliations [...] in terms of descent, kinship and origins”.

\section{Method}

Data were collected between 2005 and 2009 in different settings: numerous patients' homes, two public hospitals in the capital area (Muscat) and one outside, two public healthcare centres in Muscat, two genetics/haematology public labs, and the only patient association. This study entailed long-term field immersion, as well as in-depth interviews, about 30 of them with patients and 30 with health professionals. This was complemented by observation periods (about 12 months): direct observation in hospital settings, participant observation in the patient association and in some patients' homes. In this paper, as in any public display or publication of this research, pseudonyms are used and some background information is

\footnotetext{
${ }^{5}$ Figures vary from 3000 to 8000 (i.e. 13 to 33 of 10000 inhabitants) depending on the study. 8000 appears a plausible number on the basis of the author's observations.

${ }^{6}$ For an in-depth discussion of the entanglements of racial/ethnic categories, genetics and population genomics on the basis of the sickle-cell example, see Carter and Dyson 2011.
} 


\section{Beaudevin}

modified, in order to ensure participants' anonymity ${ }^{7}$. However, the identity of officials met within the frame of their professional duties are conserved, unless they requested to remain anonymous.

This contribution will first discuss in which respects the current social impact of inherited blood disorders in Oman is locally labelled and can be anthropologically considered a crisis. Several of the diversification processes spurred on by inherited blood disorders will then be addressed: the dynamics of disease taxonomies; the changes within the healthcare system; the biopolitics used by the authoritarian regime to manage IBD; finally, the complex interactions between the Omani social "diversity system" (Barth 1983, 83) and the transversal emerging biosocialities based on IBD.

\section{Of vanishing oil and emerging sickle cells: the legitimacy crisis of the Omani public health}

Fassin (1996, 302) emphasizes the use of health indicators in consolidating governmental power in dictatorial South-American regimes and shows, using the former USSR's example, how publishing unsatisfactory epidemiological data can be politically risky. The Omani regime adopts the same attitude: health indicators are used as tools reinforcing its legitimacy. In this context, the incidence and prevalence of HIV/AIDS, or the exact number of children born to unmarried women have long been concealed or underestimated. On the other hand, the dramatic change in the sanitary conditions in the last four decades is often cited, from the unique missionary hospital of 1970 to the ranking of the healthcare system, " 1 st among emergent countries" for its "performance according to the impact on health," and $8^{\text {th }}$ for its "global performance" in 2000 (World Health Organization, 2000). Health achievements have been long used to convey a positive image of the Omani government, as a member of the first cabinet formed by the sultan in 1970 avowedly states:

We were a new government, that's why people expected a lot from us; we had to do something, very quickly. [...] there were political contingencies ${ }^{8}$, people had to trust their leader. (interview, Muscat, Nov. 2008).

Nowadays, public health is mentioned in every edition of the state-controlled national newspapers: decreasing infant mortality, the availability of new medical facilities in a regional hospital, a large-scale blood donation campaign by employees of a ministry, the opening of a new healthcare centre, etc. Infectious diseases are mostly under control and Oman has thus entered a phase of epidemiological transition that attracted the authorities' attention to noncommunicable disorders.

Congenital blood diseases: Around $10 \%$ of Omani people are carriers of gene of sickle cell anemia and 3\% are carriers of gene of Beta-thalassaemia. Approximately 120 children are born yearly with sickle cell anemia and 20 with Beta-Thalassaemia. It is expected that through the next 10 years the number of the cases will increase to be 1200 cases of sickle cell anemia and 200 cases of thalassaemia if the preventive measures are not provided. The curative

\footnotetext{
${ }^{7}$ Given the Omani political context, anonymity often was the necessary condition of non self-censured discourses.

${ }^{8} \mathrm{He}$ alludes to the civil war taking place at this time in the Southern part of Oman (Dhofar): Omani opponents allied with China and South Yemen were fighting the sultan's army, with the aim of implementing a "popular democratic republic” in the Arabian Peninsula.
} 
management of all these new cases could cost about $\$ 17$ million yearly while provision of preventive methods cost about $10 \%$ of this sum. One case of Beta-Thalassaemia or two of sickle cell anemia may save $\$ 500.000$. (Ministry of Health 2006)

The above apprehensive discourse is taken from the "Seventh five-year plan for health development 2006-2010" published by the Ministry of Health. It provides a glimpse of the governmental approach to the IBD issue: the prevalence and incidence of IBD are considered high, their financial impact is unsustainable, the cost of every case is significant. There is thus a need for immediate public health action. From the point of view of the Omani authorities, IBD, as in the case of other non-communicable serious disorders, represent a crisis situation, since they jeopardize the 'usual' (political) efficiency of the healthcare system itself.

Since its ex-nihilo creation in 1970, the Omani Ministry of Health has implemented primary healthcare with notable and acknowledged efficiency ${ }^{9}$. Biomedicine became part of Omanis' everyday life: the vast majority of them is born in public maternity wards, everyone has to be seen by a doctor during his/her school years, STDs screening is mandatory before getting married, etc. The demographic transition resulted in a new epidemiological profile, and the main causes of death in Oman were no longer infectious diseases, but rather accidents and hereditary, degenerative or chronic disorders. The number of cases of IBD and their impact on the healthcare system thus became more and more obvious. This situation represents the root of the construction of inherited blood disorders as a national crisis: it sheds light on unsatisfactory health indicators for the regime and is a new challenge that is not only sanitary, but political as well.

Since the 1990s, health education messages have gradually intensified: in 2000, for example, the Ministry of Health published a survey (Al-Riyami 2000, the only Omani survey about genetic disorders so far) that specifically focused on IBD and tried to assess their prevalence. Media coverage, strictly driven by the State, follows this trend and emphasizes the impact of inherited blood disorders, with headlines such as: "Doctors urge pre-marriage genetic screening to combat blood disorders" (Kabeer, 2010), "Incidence of genetic blood diseases in Oman among highest worldwide" (Al-Tauqi, 2012), "60pc Omanis are carriers of blood genetic disorders" (Oman Daily Observer, 2011), "OHBDA calls for pre-marital tests to curb genetic disorders” (Muscat Daily, 2011), "120 born with Sickle Cell yearly” (Kabeer, 2012), or "Blood disorders on the rise" (Khalfan, 2011). Affecting about 8000 Omanis, these diseases constitute a significant financial burden for the healthcare system, mainly due to treatment costs (necessary, regular blood transfusions and the specific drugs needed to manage both immunity and blood iron overload).

This situation is all the more a matter of concern in that it takes place in the context of a rentier welfare state, experiencing the current worrying global financial crisis and looming austere future prospects in light of drying oil wells ${ }^{10}$. In this regard, the Omani situation echoes the history of IBD in Cyprus: in the 1940s, the discovery of the high prevalence of thalassaemia mutations in the island (about $15 \%$ of the population; Angastiniotis, Kyriakidou, and Hadjiminas 1986) made clear that policies had to be implemented to avoid the bankruptcy of the healthcare system, which was unable to pay for the daily care of thousands of new patients. (Weatherall 1998) A prevention program was implemented, involving the religious authorities: premarital screening became mandatory to get a marriage licence, and medical termination has been allowed. In the 1980s, the incidence of thalassaemia had decreased by $97 \%$. IBD in Oman, being costly for the healthcare system and

\footnotetext{
${ }^{9}$ For example: measles immunization coverage in Oman is $97 \%$ and $100 \%$ of expecting mothers have accessed prenatal care facility once (World Health Organization 2009).

${ }^{10}$ Oil extraction represents about 80 \% of Oman's GDP. The current 'proven oil reserve' of Oman is approx. 5500 billions of barrels (Radler, 2008, allowing only 17 more years of exploitation with the daily extracted quantity reached in 2011.
} 


\section{Beaudevin}

deprived of predictable evolution, contribute to keeping the hidden 'vanishing-oil wound' open and visible: the oil income is not explicitly mentioned by authorities as a source of development funding (the sole sultan's will is), and its decade and a half long life-expectancy is dodged by the official discourse. Limbert (2002, 34) tells about her ethnographic encounter with

$a$ [n Omani] wealthy businessman in the capital region [who] leaves his old palm-frond house in the backyard of his new mansion saying that it is there to remind him where he came from and where he will one day return.

As in the contrast between this old house and the neighbouring villa, the intensity of the governmental concern raised by the social impact of IBD and the difficulties of affected individuals' everyday experiences shed a garish light on the usually concealed coming end of the oil-rich era. They are among the harbingers of oil rarefaction.

Out of this multi-dimensional crisis related to inherited blood disorders in contemporary Oman, new social arrangements have emerged. The following sections will address these diversification processes.

\section{Of faqr al-dam wirâthi, new biopolitics and biolegitimacy: IBD-induced social diversifications}

\section{Diversification of nosological categories}

Among inherited blood disorders, sickle-cell anaemia and beta-thalassaemia are the two biomedical nosological entities targeted by this contribution. One of their common characteristics is a relative invisibility (or at least, a non-specificity) of symptoms, despite the potential severity of their medical prognosis ${ }^{11}$.

Figure 1 constitutes an overview of the different taxonomies used to designate the diseases. It has been built on the basis of specialized biomedical literature (genetics and haematology) and primary data gathered in Oman (interviews and ethnographic observation). These two nosological units outline a 'pathological area' (grey-coloured in Figure 1) that is differently named by biomedical and popular ${ }^{12}$ classifications. The upper part of the schema shows the two parallel biomedical taxonomies (genetic and haematological). The bottom part provides details about popular nosology, shows its intersections and overlaps with the biomedical classifications. Popular nosology does not usually differentiate between sickle-cell anaemia and thalassaemia. Most of the time, the generic Arabic phrase faqr al-dam ("poverty / indigence of the blood," "anaemia" in biomedical Arabic) is used, sometimes complemented by a precision regarding inheritance (wirâthi, "inherited”). Neither faqr al-dam nor wirâthi are modern terms. However, their association as a phrase is very recent in Oman: there were no distinct nosological entities for IBD in the lay-representations before 1970 and the diffusion of biomedicine in the country. Their symptoms were described among others, without being gathered into defined syndromes. Saif (an Omani man, aged about 70) explains about his youth:

Nobody talked about faqr al-dam separately, it was part of something else, something bigger ${ }^{13}$.

(Interview, Muscat, December 2008)

\footnotetext{
${ }^{11}$ Which is more severe for thalassaemia in resource-poor settings, while situations are more various for sicklecell anaemia: it is possible to survive the disease (for an example in contemporary Senegal, see Fullwiley 2011) without biomedical treatment.

${ }^{12}$ As opposed to "professional”, and more specifically to "biomedical professional”.

${ }^{13}$ This echoes the African nosology described by Konotey-Ahulu (Konotey-Ahulu 1991 cited in Carter and Dyson, 2011), where sickle-cell induced joint pain crises where labelled as 'rainy season rheumatism'.
} 
The current terminology has been introduced in the country together with the biomedical nosological taxonomy. One of the first biomedical practitioners of Oman tells disdainfully of the paradigms and taxonomies he came across in the country in the 1970s:

There was awareness, because of observation of marriages, that some problems were inherited, that's all. At that time, they were thinking in an unbearable way. [...] Sickle cell and thalassaemia [NDA: which were not named as such] were part of God's will. People didn't know, they were saying it was written by God. They didn't name the problem. (Interview, Muscat, November 2008).

Herrick described sickle-cell anaemia in Chicago in 1904 (Herrick 1910) and Cooley gave the first clinical account of thalassaemia in 1925 (Cooley and Lee 1925). Yet inherited blood disorders were not spotted and named, nor affected individuals and carriers "made up" (Hacking 2006) as social categories by biomedical knowledge in Oman until the 1970s.

\section{Diversification and development within the organization of the healthcare system}

IBD are among the most frequent congenital disorders in Oman, and their management has led to the implementation of new biomedical practices: the creation of blood banking facilities has been boosted by the monthly transfusions needed by numerous patients; lab technologies are being implemented all over the country, so that the cheap blood test (haemoglobin electrophoresis) sufficient for diagnostic purposes can be performed in every region; and new drugs (or recent ones like Exjade, a iron chelator produced by Novartis) are being tested in ongoing clinical trials, conducted in Oman's sole University hospital.

Among these diversification processes occurring in the healthcare system, it is noteworthy that the management of IBD opened up the way for genetics (genomics, clinical genetics, as well as 'community genetics'); the first sequencing facility was allocated to the Haematology Department of Sultan Qaboos University Hospital and has been widely used by Omani researchers to determine the specific Omani variants of genetic mutations causing IBD. The beginnings of clinical genetics are also linked to haemoglobinopathies, since the risk for parents of having another affected child had to be assessed and expressed through genetic counselling. This has not yet been officially implemented on a national level but has been provided for years in different hospitals and healthcare centres, in more or less informal settings: in a big public hospital, 'in haste' counselling was often observed, such as this doctor, meeting in the corridor the sibling of one of her patients and asking him (through the translation of a nurse) "have you been tested?". The young man answers he knows he's a carrier. The doctor then tells the nurse: "OK, then tell him he has to get his wife tested before getting married!" and turns back to her work. Regarding the specific field of "community genetics $^{14}$, the significant prevalence of IBD, the cost of their treatment and their relatively easy lab diagnosis have all contributed to pushing for the creation of a national screening program in Oman. The Omani government has not yet opted between newborn screening aiming at diagnosing IBDs in still-asymptomatic infants (in order to start treatments and health education as early as possible), premarital screening looking for carrier couples ${ }^{15}$ or a combination of these two approaches. However, neonatal screening has been systematically

\footnotetext{
14 'Community genetics' is a medical field created in the late 1970s that combines public health and clinical genetics. It aims at implementing screening programs, genetic counselling and information for people affected by hereditary diseases.

${ }^{15}$ These kinds of programs usually aim at decreasing the number of affected children by detecting (with haemoglobin electrophoresis) individuals carrying mutated genes and offering genetic counselling regarding the transmission risk in case two carriers consider getting married. Such programs have been implemented in Iran, Saudi Arabia, United Arab Emirates and Cyprus (Angastiniotis, et al. 1986; El-Hazmi 2006; Najmabadi, et al. 2006).
} 


\section{Beaudevin}

performed for years in the University Hospital, pilot-programs of premarital screening are being tested (see below, Beaudevin 2010 and forthcoming-a) and a dedicated committee has been created within the Ministry of Health.

Thus, transfers of genetic knowledge to the recent Sultan Qaboos University College of Medicine (created in 1986) and Ministry of Health (1970) have led to the political labelling of IBD as a national public health problem, a sanitary crisis endangering future generations as well as the healthcare system itself. Therefore, it is relevant to observe the biopower ${ }^{16}$ exerted by the Omani regime over its citizens, and the diversification of its forms, when it comes to IBD. The two following sections address modalities and consequences of this biopower within the dual framework of biopolitics (Foucault 1998) and post-Foucaldian biosocialities.

\section{Shifting biopolitical pattern}

As mentioned earlier, the Omani healthcare system has been designed in close cooperation with the World Health Organization (WHO) since 1970. Its current governance follows the main WHO guidelines of a pyramidal referral system consisting of three care levels: local health centres, providing primary healthcare; regional hospitals for secondary (that is, more specific) care and tertiary hospitals for advanced care (in the capital area). Furthermore, as mentioned above, health represents a significant political stake, a kind of governmental showcase in Oman (Beaudevin forthcoming-b).

Thus, managing the population as a group of bodies (i.e., exercising biopower) soon became a core aspect of the Omani governmental activity. It is important to emphasize that the very notion of citizenship in Oman is already linked to a certain extent with biological aspects: on one hand, it can indeed represent a kind of "talisman" (Lavergne 2005, 9), since it entitles its holder to free ${ }^{17}$ healthcare, among other social benefits. Excluded from this benefit is about a quarter of the country's inhabitants, mostly migrant workers from Asia — single or, if married, very rarely accompanied by their spouse or family. On the other hand, one can consider this status as based on biology, since an individual can only be Omani because of genetic linkage through patriliny: nationality is most of the time granted through lineage and theoretically impossible to get by other means ${ }^{18}$.

Regarding inherited blood disorders and, more broadly, genetics, the Omani regime stands at a crossroads: a pattern of screening policy is currently being tested in several regions of the Sultanate and will most likely be implemented all over the country in the near future. It consists of non-mandatory premarital testing, offered to any volunteer couple and followed once the results are available, usually after two weeks - by a basic genetic counselling session. In practice, tested individuals are not only engaged young adults, but also single or even married adults. If the individual is screened as a carrier, the resulting decision has potentially heavy consequences on his/her life course: it can either result in an avoidance of marriage ${ }^{19}$ with another carrier, in divorce, or even in the decision not to have children if one is already married to a carrier. But the first consequence of this recent use of biomedical technologies to search for heterozygous individuals (i.e., carriers of the affected gene) is the appearance of a new abnormality category: even if carriers do not suffer any symptoms, they are labelled abnormal, since their children can inherit the mutated gene.

\footnotetext{
${ }^{16}$ In the Foucaldian sense of exercising power over bodies and, more specifically, of a State exercising this power over an entire population's bodies.

${ }^{17}$ Except for a minor administrative fee which must be paid for every visit (about 0,5€).

${ }^{18}$ Except for expatriates who were granted Omani citizenship as a reward (for example: 37 individuals in 2007 according to the Ministry of National Economy 2009, 461), and residents living in Oman for decades.

${ }^{19}$ Given that marriage is the social frame of the immense majority of births in Omani society.
} 
Furthermore, the decision to implement a universal screening policy implies several ethical and organizational issues: is neonatal screening necessary too? Who will get tested targeted groups or the whole population? Will the regime still allow an individual carrying affected genes to get married to another carrier? Will prenatal diagnosis be offered as well? If yes, will pregnancy termination be allowed for affected foetuses (as in Iran or Saudi Arabia? ${ }^{20}$ ) How will new cases be managed? These few questions, which have not yet been firmly answered by the Omani policy makers, show how deeply the exertion of biopower would intervene with the intimacy and everyday life of Omani citizens in order to control the incidence of IBD. Regarding marriages between carriers of IBD mutations who know about their genetic status, some rare doctors do not hesitate to call for rigorous (and brutal) measures:

In my opinion, this [IBD carrier marriages] won't disappear if government does not step in. They will continue. The government has to rule against this! Or to make blood tests compulsory. And if one of the couple is a carrier, either he or she is sterilized, or there is no wedding. Now, marriages are registered by the mullah [NDA: he is a Shia Muslim and thus does not use the term 'imam'] who fills in the form that the couple then signs. Then it is saved in the central computer. We should put a column for blood tests. One has to be a bit tough. To be cruel to do good. [...] We've reached the point where premarital tests should be compulsory. (Interview, Muscat, Nov. 2008).

Scrutinizing matrimonial behaviour has always been part of the regime's policy: the Omani law restricts choice of one's spouse, especially if s/he is not an Omani citizen. However, the 1980 Royal decree forbidding marriages to non-Omanis has been gradually amended: nowadays, marrying a Gulf Cooperation Council ${ }^{21}$ national is allowed, and marrying someone outside GCC has been theoretically possible since 1993 but requires the agreement of an ad-hoc inter-ministerial committee on the basis of "valid social and health reasons" (Limbert 2007, 172). In this context, the observed ${ }^{22}$ pressure to discourage marriages of carriers is actually 'only' one more manifestation of the pervasive State biopolitical strategy, which could be partly defined as 'controlling difference'; despite the absence of official instructions, zealous practitioners participate in keeping the Omani "social diversity system” (Barth 1983) intact. In addition, several individuals in charge of designing the screening policy in Oman consider displaying genetic status for IBD on identity cards an option. As striking as this idea can appear ${ }^{23}$, one has to notice that Omani policies are being designed in a regional context of emphasis on genetics within biopolitics: the 'Identity Authority' of the United Arab Emirates is, for instance, implementing a universal biobank for security purposes (Al-Khouri 2010; Lori 2010).

The following section will deal with the interactions between the intricately stratified Omani social structure and the new category represented by people affected by IBD, i.e., one more diversification process occurring on the backdrop of the IBD public health crisis.

\section{Diversification of social institutions: emerging biosocialities?}

As stated above, recent use of biotechnologies to screen the Omani population led to the appearance of carriers as a new social category of abnormal individuals. Together with affected people and their families, carriers represent, as a whole, a new subgroup in the

\footnotetext{
${ }^{20}$ El-Hazmi 2006; Najmabadi, et al. 2006

${ }^{21}$ I.e., (apart from Oman) Kuwait, Bahrain, Saudi Arabia, Qatar and the United Arab Emirates.

${ }^{22}$ In the "test institutions" where the policy is implemented.

${ }^{23}$ It also recalls the highly criticized suggestion of Linus Pauling (Pauling 1969), the American biochemist who discovered the biomolecular mechanism of sickle cell anaemia: he called for carriers of sickle cell anaemia to be tattooed with their genetic status on the forehead, so that they could "avoid falling in love" with each other.
} 


\section{Beaudevin}

Omani society. Paul Rabinow (2005 [1992]) defined "biosocialities" as the sociality phenomena organized on the basis of a biological fact. Associations of people affected by the same disease are archetypal of this concept. But associations are strictly controlled in Oman, as well as any group not directly linked to a governmental body. ${ }^{24} \mathrm{Al}$-Azri (2008, 218-219) clearly expresses the historical roots of this rigid monitoring:

[...] the war in Dhofar ${ }^{25}$ played an important role in the direction of the State's policies since 1970. For instance, as early as 1974, the Criminal Code of the State prohibited the establishment of any organization that does not comply with the State's basic principles and social and economic goals, as stated by Article 134 of this Code. This article does not clarify what these principles are or what it means by the State's social and economic goals. Arguably, the State possesses unquestionable control over public interest and public debate, even when such interest and debate do not conflict with the general rules that guide State policy.

Despite such strict control, the Oman Hereditary Blood Disorders Association (OHBDA) was authorized in June $2009^{26}$. Its members are patients, families and doctors, all of them from different social backgrounds but sharing a common fate, shaped by the prognosis of the diseases.

Even before the 2011 Arab Spring events, health was one of the few social issues easily provoking open criticism in Oman. Patients' associations constitute one of the rare social settings where health issues are discussed on the basis of personal embodied experience. The Omani Fundamental Law clearly specifies that the State "endeavours to provide healthcare for every citizen," 27 thus establishing a clear governmental responsibility regarding the citizens' well-being (and an open door to biopolitical strategies). In such a context, affected people's associations like OHBDA are potentially fertile grounds for social protest. Several interviewed affected individuals were indeed asserting the State's responsibility regarding poor treatment facilities and the appearance of new cases of inherited blood disorders ${ }^{28}$. This explanatory model of the disease has been recently called "political aetiology" in other Middle-Eastern settings (Hamdy 2008). In the 1980s, Fainzang (2000) described such accusations in Europe as a striking contrast with the West African societies she previously studied, where individuals are more easily blamed for illnesses. She called this distinctly Western process "subversive causality" in the sense that "casting the blame on 'Society' in the West is an expression of the interpreter's desire to change it." In these Omanis' views, implementation of public health policies aimed at controlling the diseases is a governmental duty towards citizens. The occurrence of such an accusation pattern in a tribal society is an interesting path of research.

Such a situation provides the conditions for the emergence of a biological citizenship $^{29}$. This concept is used here in the sense defined by Adriana Petryna $(2005,173)$ in her research on post-Chernobyl irradiated individuals' movements, namely biological citizenship as a formalized biosociality. Biosocialities do indeed gather people sharing a common biological condition, and through formalization and/or increased social visibility,

\footnotetext{
${ }^{24}$ Fundamental Law, article 33.

${ }^{25}$ See note 8 .

${ }^{26}$ Oman Hereditary Blood Disorders Association, http://www.omancares.org

Two other patients associations already existed: the Oman Diabetes Society and the National Association for Cancer Awareness.

${ }^{27}$ Article 12 [Social Principles]

${ }^{28}$ Available figures are differing but one can roughly consider that the incidence of sickle-cell anaemia and thalassaemia in Oman is about 20 to 100 new cases per year.

${ }^{29}$ In the Omani context, citizens paradoxically seem to request an increase of state control on body and health. This is partly diverging from other studies addressing biological citizenship together with autonomy, but this paper argues that some aspects of the concept have to be defined differently within authoritarian political contexts.
} 
they can become effective platforms to formulate social claims for rights based on this common medical condition itself (inherited blood disorders here). Another pillar of the concept of biological citizenship is "the role of the state and other large, stable institutions as guarantors of healthcare and social security." (Nguyen 2010, 109) The creation of institutions such as the Oman Hereditary Blood Disorders Association implies a collective demand for acknowledgment of "biolegitimacy" (Fassin 2009, 51). Given the social diversity of the association's members, this event is transcending the usual Omani social hierarchical categories and thus contradicting the regime's categorization pattern. Since 1970, the Omani regime has indeed been preventing individuals from weaving transversal links (based on common public interest, for instance) by reinforcing intratribal links. Any transversal link is supposed to limit one's sense of belonging to social groups (tribes) which are, firstly, easier for the state to control and secondly, fit within the "Omanity" it has shaped ${ }^{30}$ since 1970. Therefore, any kind of transversal link is a potentially disturbing social fact.

Nevertheless, these biosocialities and their consequences are currently in embryo in Oman. Predicting to what extent a common suffering could transcend social categories and bring together, for example, rich merchant families' members and individuals whose ancestors were slaves, is indeed arduous. Therefore, it is important to follow up the outcomes and social consequences of biosociality phenomena in Oman in the coming years, all the more as the 2011 Arab Spring's long-term consequences for the Gulf are not yet $\mathrm{known}^{31}$. However, about the small neighbouring kingdom of Bahrain, Dyson and Atkin (2012) pointed out the claims of Human Rights Watch (2011) regarding the oppression on arrested sickle-cell patients and carriers, whose deaths in custody after torture seem to have been relabelled as 'sickle-cell related'. In the context of the Arab Spring, such events, added to the growing number of sickle-cell patients dying in the Salmaniya Hospital in Manama ${ }^{32}$, led the Bahrain Society for Sickle-Cell Patient Care ${ }^{33}$ and patients' families to publicly question the regime's management of sickle-cell anaemia as a public health matter (Gulf Daily News 2012c, 2012b, 2012d). So far, the Bahraini Ministry of Health has reacted with mediatised promises of an improved protocol and a new and extended treatment unit (Bahrain News Agency 2012).

\section{Conclusion}

The Omani context is a striking example of the way increased biomedical knowledge and the outcomes of its applications can affect a society. Even if inherited blood disorders were present in Oman long before 1970, they had not yet been individualized within the popular nosologies. Genetic knowledge practices and the diffusion of biomedical nosologies have since contributed to the diversification of nosological entities that now entangle popular and biomedical categories. On a national level, IBD have progressively been defined as a public health priority, a financial and sanitary crisis that must still be solved. This has led to another diversification process within the healthcare system itself: the appearance of genetic labs, the beginnings of clinical genetics, and the testing of community genetics policies.

Considering the Omani situation through the crisis lens allows several aspects to be emphasized: from the dark economic future represented by the management of IBD to the necessary disruption of the former public health pattern that was focused on primary

\footnotetext{
${ }^{30}$ The term “Omanity” (Valeri 2007; Valeri 2009) has been chosen on purpose, instead of “Omaniness” Chatty 2009: the suffix -ity indeed expresses a more abstract (less embodied) condition than -ness. This appeared more suitable to name a social and political construction.

For more details regarding this construction of an Omani national identity, its political stakes and the general political background, see Valeri 2009.

${ }^{31}$ For details about the 2011 and 2012 events in Oman, see Valeri 2011 and Worrall 2012.

${ }^{32}$ Reported to be 37 in the last 8 months as of October 2012 (Gulf Daily News 2012a)

33 http://www.scdbh.net/
} 


\section{Beaudevin}

healthcare for all. Aiming at fulfilling WHO objectives and securing its legitimacy through public health achievements, the Omani regime has long been exercising a strong biopower over the population. Its biopolitics applied to IBD arise from the construction of a prevention crisis and not a therapeutic crisis: policies and projects are meant to reduce the incidence of IBD by controlling the population's behaviour, but are not meant to directly improve therapeutic possibilities in the country. The ongoing implementation of a national premarital screening program and genetic counselling for IBD aims at controlling the 'difference' constituted by carriers of mutated genes and their potentially affected offspring. This partly represents a supplementary manifestation of the regime's governmentality in the Foucaldian sense of the "encounter of techniques of domination exerted on others and technologies of the self” (Foucault 1994, 785).

Through the appearance of a patient's association, people affected by and carrying genes of inherited blood disorders start to organize themselves into a new kind of social institution that constitutes a potential disturbance of the Omani social and political order. Allowing people from different tribes and social settings to meet and share (burdensome) life experiences, such an association could lead to a new kind of social protest based on a common genetic condition.

\section{Acknowledgements}

This research was funded by the French Ministry of Higher Education and Research, the French Society for Perinatal Medicine (SFMP), the French Centre for Archaeology and Social Sciences of Sana'a (CEFAS, Yemen) and the French Embassy in Oman. Fieldwork has been supported by the College of Arts and Social Sciences, Sultan Qaboos University, Muscat, Oman. Ethical approval was obtained from the Research and Ethical Committee of the Omani Ministry of Health. The author would like to express her gratitude to patients, families and health practitioners in Oman, for their trust and the way they let her settle into their everyday lives, in hospitals or at home, in Muscat and elsewhere. She would also like to thank the editors of this special issue, the three anonymous reviewers, as well as Anne Marie Moulin, Jean-Paul Gaudillière, Sylvie Fainzang, MaryAshley Ouvrier, Susann Huschke, Dominik Mattes and the members of the Cermes3 doctoral seminar for their highly valuable comments on earlier versions of this text.

Conflict of interest: none.

\section{References}

Al-Azri, K. 2008. Development, Culture and the Dilemma of Equality in 'modern' Omani Society: The Practice of Kafa'a in Marriage and Talaq. PhD diss., University of Melbourne.

Al-Khouri, A. 2010. The Question of Identity in the Gulf (United Arab Emirates Identity Authority). Paper presented at The 2010 Gulf Conference, at Institute of Arab and Islamic Studies, June 30-July 3, University of Exeter, United Kingdom

Al-Riyami, A. 2000. National Genetic Blood Disorders Survey. Muscat: Ministry of Health.

Al-Riyami, A.A., A.J. Suleiman, M. Afifi, Z.M. Al-Lamki, and S. Daar. 2001. A communitybased study of common hereditary blood disorders in Oman. Eastern Mediterranean Health Journal 7, no. 6:1004-1011.

Al-Tauqi, Z., 2012. Incidence of genetic blood diseases in Oman among highest worldwide. Muscat Daily, October 16. 
Angastiniotis, M., S. Kyriakidou, and M. Hadjiminas. 1986. How thalassaemia was controlled in Cyprus. World Health Forum 7:291-297.

Anionwu, E.N., and K. Atkin. 2001. The Politics of sickle cell and thalassaemia, Race, Health and Social Care. Buckinghamand Philadelphia: Open University Press.

Bahrain News Agency. Meeting on Sickle Cell Protocol Set 2012 [Bahrain News Agency. http://www.bna.bh/portal/en/news/516044].

Barth, F. 1983. Sohar:culture and society in an Omani town. Baltimore and London: Johns Hopkins University Press.

Beaudevin, C. 2010. Faqr al-dam, "l'indigence du sang", comme héritage. Représentations et enjeux sociaux des hémoglobinopathies héréditaires au sultanat d'Oman. [Faqr al-dam (indigence of the blood) as inheritance. Representations and social stakes of hereditary haemoglobinopathies in the Sultanate of Oman]. PhD diss., Université Paul Cézanne d'AixMarseille.

Beaudevin, C. Forthcoming-a. Cousin marriages and inherited blood disorders in the Sultanate of Oman. In Cousin marriage: between tradition, globalisation and genetic risk, ed. A. Shaw and A. E. Raz. London and New York: Berghahn.

Beaudevin, C. Forthcoming-b. Of red cells, translocality and origins: inherited disorders in Oman. In Regionalizing Oman. Political, economic and social dynamics, ed. S. Wippel. Dordrecht: Springer Science.

Bonnet, D. 2009. Repenser l'hérédité. Paris: Editions des archives contemporaines.

Carter, B. 2009. The politics of provenance: Genetics, culture and identity. In Racism and Justice: Critical Dialogue on the Politics of Identity, Inequality and Change, ed. S. Hier, D. Lett and B. B. Singh. Halifax: Fernwood.

Carter, B., and S. M. Dyson. 2011. Territory, ancestry and descent: the politics of sickle cell disease. Sociology 45, no. 6:963-976.

Centre for Arab Genomic Studies. Sickle cell disease. CAGS 2008. http://www.cags.org.ae/sickle.pdf.

Chatty, D. 2009. Rituals of Royalty and the elaboration of ceremony in Oman: view from the edge. International Journal of Middle East Studies 41:39-58.

Cooley, T.B., and P. Lee. 1925. Series of cases of splenomegaly in children with anemia and peculiar bone changes. Transactions of the American Pediatric Society 37:29.

Dyson, S. M., and K. Atkin. 2012. Sickle cell and thalassaemia: why social science is critical to improving care and service support. In Genetics and Global Public Health: Sickle Cell and Thalassaemia, ed. S. M. Dyson and K. Atkin. London: Routledge.

El-Hazmi, M. 2006. Pre-marital examination as a method of prevention from blood genetic disorders. Community views. Saudi Medical Journal 27, no. 9:1291-1295. 


\section{Beaudevin}

Fainzang, S. 2000 [French ed. 1989]. Of Malady and Misery. An Africanist Perspective of Illness in Europe. Amsterdam: Het Spinhuis Publishers.

Fassin, D. 1996. L'Espace politique de la santé - Essai de généalogie, Sociologie d'aujourd'hui. Paris: PUF.

Fassin, D. 2009. Another politics of life is possible. Theory, Culture \& Society 26, no. 5:4460.

Foucault, M. 1994. Dits et écrits, tome IV. Paris: Gallimard.

Foucault, M. 1998. The History of Sexuality. Vol.1 of The will to knowledge. London: Penguin.

Fullwiley, D. 2011. The Enculturated Gene: Sickle Cell Health Politics and Biological Difference in West Africa. Princeton: Princeton University Press.

Gulf Daily News. 37th sickle cell death 2012a [Gulf Daily News http://www.gulf-dailynews.com/NewsDetails.aspx?storyid=339211].

Gulf Daily News. Sickle cell activist in hospital 2012b [Gulf Daily News from http://www.gulf-daily-news.com/NewsDetails.aspx?storyid=333058].

Gulf Daily News. Sickle cell man dies in custody. 2012c [Gulf Daily News http://www.gulfdaily-news.com/NewsDetails.aspx?storyid=338983].

Gulf Daily News. Sickle cell patient dies 'awaiting bed' 2012d [Gulf Daily News http://www.gulf-daily-news.com/NewsDetails.aspx?storyid=335206].

Hacking, I. 2006. Making Up People. Clinical classifications. London Review of Books 28, no. 16:23-26.

Hamdy, S.F. 2008. When the state and your kidneys fail: Political etiologies in an Egyptian dialysis ward. American Ethnologist 35, no. 4:553-569.

Herrick, J.B. 1910. Peculiar elongated and sickle-shaped red blood corpuscles in a case of severe anemia. Archives of Internal Medicine 6:517.

Human Rights Watch. Bahrain: Suspicious Deaths in Custody. 2011 [Human Rights Watch http://www.hrw.org/news/2011/04/13/bahrain-suspicious-deaths-custody].

Kabeer, Y., 2010. Doctors urge pre-marriage genetic screening to combat blood disorders. Oman Daily Observer, June 26.

Kabeer, Y., 2012. 120 born with Sickle Cell yearly. Oman Daily Observer, September 22.

Khalfan, M., 2011. Blood disorders on the rise. Oman Daily Observer, May 8.

Konotey-Ahulu, F.I.D. 1991. The sickle cell disease patient. London: Macmillan Education. 
Lavergne, M. 2005. Sur les ailes du désir, de Koweït à Mascate. Villes et territoires du Moyen-Orient 1.

Limbert, M.E. 2002. Of Ties and time : sociality, gender and modernity in an Omani town. PhD diss., University of Michigan, Flint.

Limbert, M.E. 2007. Marriage, status and the politics of nationality in Oman. In The Gulf family. Kinship Policies and Modernity, ed. A. Alsharekh. Londen : LMEI / SOAS.

Lori, N. 2010. Tracking Transient Flows: The Political Management of Expatriates and the Growth of the Surveillance and Security Apparatus in the UAE since the 1990s. Paper presented at The 2010 Gulf Conference, at Institute of Arab and Islamic Studies, June 30-July 3, University of Exeter, United Kingdom

Ministry of Health. 2006. The Seventh Five - Year Plan For Health Development - 20062010. Vision: Alleviation of Risks Threatening The Public Health. Muscat: Ministry of Health.

Ministry of National Economy. 2009. Statistical yearbook. Muscat: Ministry of National Economy.

Muscat Daily, 2011. OHBDA calls for pre-marital tests to curb genetic disorders. Muscat Daily, May 25.

Najmabadi, H., A. Ghamari, F. Sahebjam, R. Kariminejad, V. Hadavi, T. Khatibi, A. Samavat, E. Mehdipour, B. Modell, and M.H. Kariminejad. 2006. Fourteen-Year Experience of Prenatal Diagnosis of Thalassemia in Iran. Community Genetics 9:9397.

Nguyen, V.-K. 2010. The Republic of therapy. Triage and Sovereignty in West Africa's Time of AIDS. Durham (NC): Duke University Press.

Oman Daily Observer, 2011. 60pc Omanis are carriers of blood genetic disorders. Oman Daily Observer, June 21.

Parkin, D., Krause, K. and Alex, G. 2013. Peak or prolonged: the paradox of health crisis as subjective chronicity. Introduction to Special Issue 'Therapeutic knowledge, health, crises and processes of diversification and mainstreaming', Anthropology \& Medicine

Pauling, L. 1969. Reflections on a new biology: foreword. UCLA Law Review, 15 no. 2:267272.

Petryna, A. 2005. Science and Citizenship under Postsocialism. In Anthropologies of Modernity. Foucault, Gouvernementality and Life Politics., ed. J. X. Inda. Oxford: Blackwell Publishing.

Rabinow, P. 2005 [1992]. Artificiality and enlightenment: from sociobiology to biosociality. In Anthropologies of Modernity. Foucault, Gouvernementality and Life Politics., ed. J. $\mathrm{X}$. Inda. Oxford: Blackwell Publishing. 


\section{Beaudevin}

Radler M., 2008. New estimates boost worldwide oil, gas reserves. Oil \& Gas Journal 106(48): 20-23.

Tapper, M. 1999. In the blood. Sickle cell anemia and the politics of race, Critical Histories. Philadelphia : University of Pennsylvania Press.

Valeri, M. 2007. Something stirring under the Still Waters of Oman. Tightening the Grip or Revitalizing the Monarchy? Chroniques yéménites 14:105-116.

Valeri, M. 2009. Oman. Politics and society in the Qaboos State. London and New York: Hurst / Columbia University Press.

Valeri, M. 2011. The Qaboos-State under the test of the Omani Spring: are the Regime's answers up to Expectations? Les Dossiers du CERI sept 2011.

Wailoo, K. 2001. Dying in the city of the blues. Sickle cell anemia and the politics of race and health, Studies in Social Medicine. Chapel Hill: University of North Carolina Press.

Wailoo, K., and S. Pemberton. 2006. The Troubled dream of genetic medicine. Ethnicity and Innovation in Tay-Sachs, Cystic Fibrosis and Sickle Cell Disease. Baltimore: The Johns Hopkins University Press.

Weatherall, D.J. 1998. Thalassemia in the next millennium. Keynote address. Annals of the New York Academy of Sciences, 30 no. 850:1-9.

World Health Organization. 2000. World Health Statistics Report. Geneva: WHO.

World Health Organization. 2009. World Health Statistics Report. Geneva: WHO.

Worrall, J. 2012. Oman: the "forgotten" corner of the Arab Spring. Middle East Policy XIX 3:98-115. 


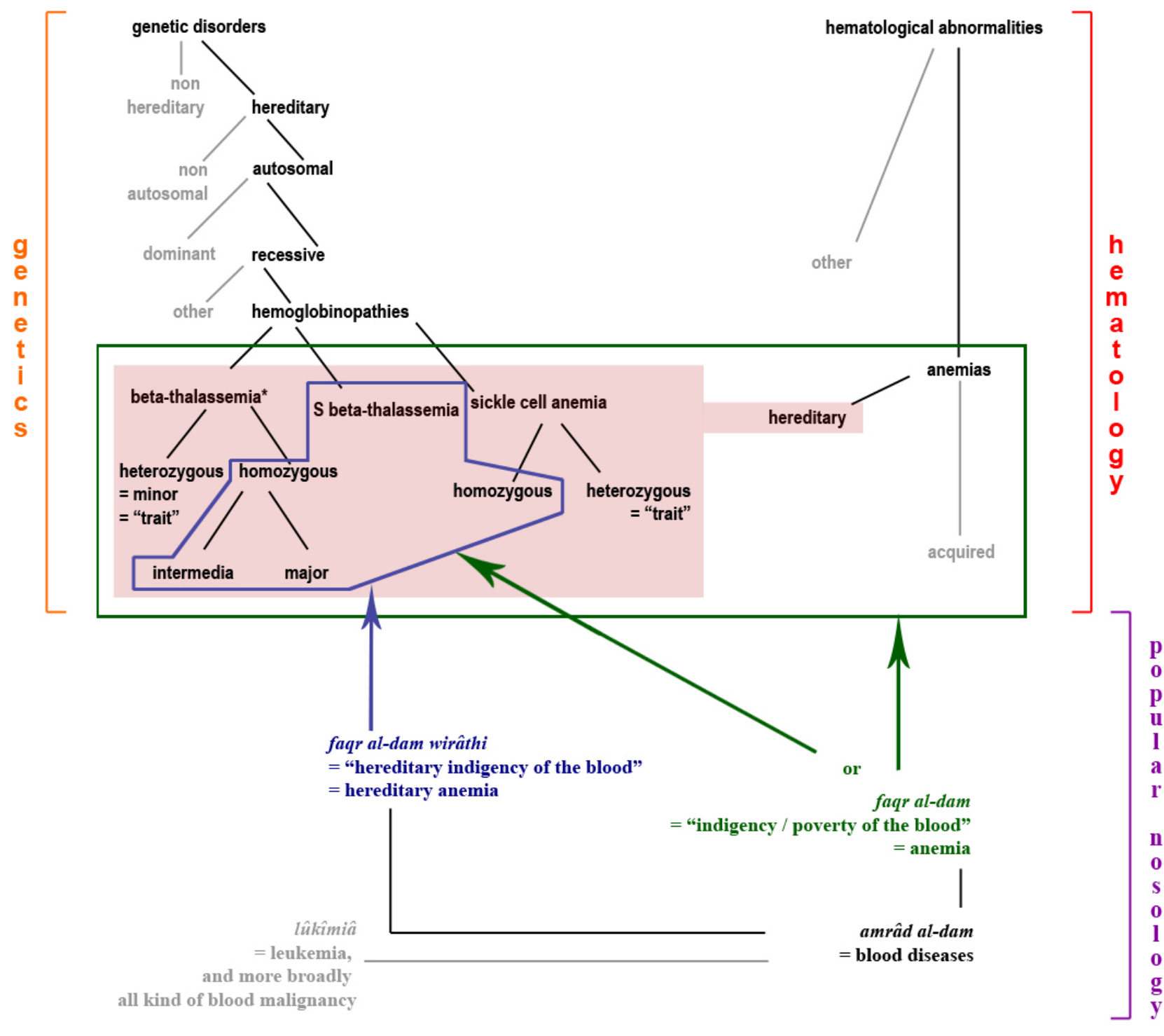

* alpha-thalassemias, not studied, aren't included in this diagram.

Figure 1 - Biomedical and popular nosologies of the studied diseases (Beaudevin, 2009) 